\title{
Comparisons of Receptive and Expressive Vocabulary Performances between Computer-and Paper-based Test in Children with Language Development Delay
}

\author{
Ji Suk Park ${ }^{\mathrm{a}}$, Seong Hee Choi ${ }^{\mathrm{a}, \mathrm{b}}$, Kyoung jae Lee ${ }^{\mathrm{a}, \mathrm{b}}$, Chul-Hee Choi ${ }^{\mathrm{a}, \mathrm{b}}$ \\ aDepartment of Audiology and Speech-Language Pathology, The Graduate School of Medical and Health Industry, Daegu Catholic University, \\ Gyeongsan, Korea \\ ${ }^{b}$ Department of Audiology and Speech-Language Pathology, College of Bio and Medical Sciences, and Catholic Hearing Voice Speech Center, \\ Daegu Catholic University, Gyeongsan, Korea
}

Correspondence: Seong Hee Choi, $\mathrm{PhD}$ Department of Audiology and Speech-Language Pathology, Institute of Biomimetic Sensory Control, and Catholic Hearing Voice Speech Center, Daegu Catholic University, 13-13 Hayang-ro, Hayang-eup, Gyeongsan 38430, Korea

Tel: $+82-53-850-2542$,

Fax: +82-53-359-6780

E-mail: shgrace@cu.ac.kr

Received: April 5, 2020

Revised: May 11, 2020

Accepted: May 16, 2020
Objectives: The purpose of this study was to explore whether children with developmental language delays' performance on the Korean Receptive and Expressive Vocabulary Test (REVT) changed depending on media type (computer-based (tablet PC) vs. paper-based).

Method: A total of 27 children with developmental language delay, ages 3 to 7 years, participated. All children were divided into two groups according to the degree of language development delay and the age of integrated language using the Preschool Receptive-Expressive Language Scale (PRES) to evaluate language development. The REVT was conducted at weekly intervals using different media in a random order. Raw score, total response time (TRT), and average response time per question (ART) were measured between different media type and compared based on the degree of language development delay and the age of integrated language.

Results: Our study found statistically higher raw scores in both receptive and expressive vocabulary test (REVT) in the computer-based test compared to the paper-based test. On the other hand, regardless of the severity of the language delay, TRT and ART were statistically significantly shorter in the computer based expressive vocabulary test, but only TRT was significantly shorter in the receptive vocabulary test.

Conclusion: In this study, in all language development delayed groups, the test results varied depending on the type of media. In particular, computer-based tests, rather than conventional paper-based tests, maintained the concentration of language-delayed children and helped reduce reaction time and improve vocabulary performance. Thus, the type of media used for the test should be considered.

Keywords: Language development delay, REVT, Language performance, Total response time, Average response time per question, Computer-based test
수용·표현 어휘력검사(Receptive \& Expressive Vocabulary Test, REVT; Kim, Hong, Kim, Jang, \& Lee, 2009)는 진단을 목적으로 우 리말을 사용하는 아동의 어휘능력을 검사할 수 있는 표준화된 어 휘 검사 도구로 여러 임상에서 널리 사용되고 있다. Kim, Hong과 $\operatorname{Kim}$ (2009)은 우리말에 대한 사전 문헌 연구에 기초하여 문항분석
을 실시하여 REVT의 검사문항을 개발하였으며, 수용 어휘력검사 와 Kim, Lee, Hong, Kim 그리고 Chang (2009)은 수용 및 표현 어 휘력을 검사하기 위해 개발 중인 ‘수용· 표현 어휘력 검사'를 실제 적용하기 위한 기초연구로서 검사도구의 타당도 검증을 위해 생활 연령과 성별을 일치시킨 4-6세의 취학 전 일반아동과 언어발달지 
체아동들을 대상으로 수용·표현 어휘력검사를 실시하였다. 검사 결과, 일반아동과 언어발달지체아동간에 집단 간 차이가 유의하게 나타남으로써 언어발달지체아동을 판별해 내는 도구로 사용하기 에 타당한 것으로 나타났다. 또한, 일반아동 및 언어발달지체아동 들을 대상으로 그림어휘력검사, 아동용 한국판 보스톤 이름대기검 사, 수용-표현 어휘력검사를 실시하여 공인타당도를 검증한 결과, 기존의 어휘검사 도구들과 높은 상관을 나타냄으로써 어휘검사로 서의 타당도가 검증되었다. 이처럼 REVT는 언어발달연구 및 언어 치료 임상현장에서 널리 사용되고 있지만, 문항수가 많고 그림책을 활용하기 때문에 검사 도구의 양이 너무 많은 단점이 있다. 이러한 이유로 Hong, Kim과 Kim (2014)은 3세 아동 1,700명을 대상으로 기존의 표준화된 어휘검사도구인 REVT문항을 반으로 줄인 간편 어휘 선별 검사를 개발하고 신뢰도를 분석하였다. 특히, 언어발달 이 지체된 3세 아동의 선별을 위해서는 어휘 능력에 대한 평가가 중 요하다고 하였는데, 언어 발달의 예후를 고려할 때 3 세는 자연적 회 복을 기대하기보다는 지속적인 지체를 나타내거나 나타낼 가능성 이 있는 연령이므로 적절한 조기중재를 제공해야 하는 시기이기 때 문이다. 또한, 이 연구에서는 기존의 인쇄물로 된 REVT검사를 실 시하였으나, 멀티미디어 및 스마트 기기에 익숙한 요즘 세대들에게 는 컴퓨터나 스마트 기기에 그림어휘를 탑재하고 자동 평가 시스템 을 활용할 수 있도록 하는 간편 어휘 검사의 개발이 필요하다고 제 안하였다.

실제로, Lee와 Kim (2009)의 연구에서는 일반 중학생들을 대상 으로 그림책으로 한 개별 검사와 교실 스크린을 통한 집단 검사로 $\mathrm{REVT}$ 의 검사 결과를 비교하였다. 그 결과, 수용어휘력 검사에서 는 검사 방법 간 차이를 보이지 않았으나 표현어휘검사에서는 두 방법 간에 유의한 차이를 보였다고 보고하였다. 이는 집단 검사의 경우 집중력 통제가 어렵기 때문일 수 있고 매체의 차이가 원인일 수 있다고 하였다. 따라서, 3 세 유아를 위한 컴퓨터 기반 REVT검 사를 시행하기 위해서는 개별 컴퓨터 또는 스마트 기기 검사의 타 당도 연구가 우선되어야 한다고 하였다(Hong et al., 2014).

최근 첨단 정보통신기술 등의 발달로 기존에 많이 사용되었던 인쇄물 같은 전통적인 매체보다는 미디어 매체를 활용하여 교육과 치료들이 시도되고 있다. 전통적인 매체인 종이 인쇄물은 종이에 글자나 그림 등을 인쇄하는 것으로 기존에 계속 사용을 해왔기 때 문에 친숙하고 익숙하게 사용을 할 수 있고 손으로 종이를 잡고 넘 기는 방법으로 촉감을 사용하여 편안하며 안정적인 느낌을 줄 수 있으나, 많은 양을 제시할 때 무게적인 부분이나 다양한 자료를 빠 르게 제시하지 못하는 등의 단점을 보이고 있다. 새로운 매체인 미 디어 매체란 무선 인터넷을 통하여 정보 접근성이 높으며 휴대성이
뛰어나고 높은 가독성과 터치를 기반으로 손쉬운 인터페이스가 특 징이며 기존에 사용되어왔던 인쇄 매체를 대체할 것으로 예상되어 지는 디지털 매체를 말하며, 전자책이나 PC, 스마트폰, 태블릿 등 이 있다(Kim et al., 2011).

최근 디지털 미디어의 사용이 보편화 되어 초기 아동 교육에서 사용되고 있으나, 디지털 미디어가 인지 과제나 언어 과제에서 미치 는 영향에 대한 이해는 부족한 편이다. Kim, Park과 Yi (2017)는 공 간 인식 과제에 대한 아동 수행이 과제를 제시하는데 사용되는 매 체 유형에 따라 달라지는지, 그리고 어린이의 연령과 성별에 따라 매체 유형의 영향이 다른지 여부를 조사하였으며, 종이 - 태블릿 기 반 검사를 이용하여 학령기 이전 정상 3-5세 아동 60명에게 과제를 제시하였다. 그 결과, 태블릿에서 작업을 완료할 때 작업 수행의 정 답률이 문서로 작업을 완료할 때와 크게 다르다는 결과를 보고하 였으며, 태블릿에서 질문을 완료했을 때 응답 시간은 문서로 작업 을 완료했을 때보다 상당히 짧았다. 비록 미디어의 종류와 나이 사 이에는 상호작용이 없었으나, 미디어의 종류와 성의 종류 사이에 부분적인 상호작용이 발견되었으며, 이 결과는 디지털 자극이 아 동 수행에 미치는 영향을 공간 인지 과제에 영향을 줄 수 있음을 시 사하였다. 또한, 한국판 동형.반복형 신경심리평가 배터리(Korean-

Repeatable Battery for the Assessment of Neuropsychological State, K-RBANS)를 사용하여 컴퓨터 기반 검사와 지필 기반 검사를 비 교하는 연구 결과, 검사 매체에 따른 K-RBANS 하위검사 수행에서 기호쓰기가 지표 수행 차이에서 주의력 지표와 전체척도 지표에서 차이가 나타남이 보고되었다(Kim, 2019).

이외에도 선행 연구에 의하면, 새로운 매체인 스마트 미디어 매 체를 활용하였을 때 아동의 집중 및 흥미 유발, 긍정적 태도의 변화 등 높은 효과가 나타나기 때문에 최근에는 스마트 미디어 매체를 활용한 분야들이 점점 증가되고 있다. 스마트 미디어 매체를 활용 할 경우 학습을 할 때 흥미를 유발하기 쉽고, 높은 집중력으로 효 과를 극대화 하였으며 종이 책 교과서나 e-러닝 환경의 데스크톱 $\mathrm{PC}$ 사용보다 주의집중력과 자신감, 만족감이 높았다고 보고하였 다(Jeong, 2015; Yeon, 2007). Lee (2005)의 연구에서도 태블릿 PC 를 활용하였을 때 학습 방법이 다양해졌으며 학습 흥미 및 학습량 이 증가되었고 수동적인 학습자의 역할에서 적극적인 모습으로 변 화되었다고 하였다. 이는 스마트폰 및 태블릿 PC는 새로운 교수매 체로서 유아 흥미 증진에 영향을 주어서 태도에서의 변화가 나타 나 긍정적인 효과가 있다고 보여진다(Yoo, 2012). 또한, Lee, Ki와 Lee (2012)의 연구에서는 취학 전 아동을 대상으로 집중을 유지하 는 시간과 학습의 효과를 연구한 결과, 책, 비디오와 같은 전통적인 미디어보다 상호작용 컨텐츠인 뉴미디어를 사용했을 때 집중을 유 
지하는 시간과 학습의 효과가 상대적으로 높은 것으로 확인되었 다. 그러나, 스마트 미디어 매체는 개발을 하는데 오랜 시간이 걸리 거나 높은 구매 비용이 들지만 현재 아동들이 많은 관심을 보이고 있어 적절한 시간과 사용하는 방법에 대한 제한이 필요할 수도 있 을 것이다.

한편, 스마트 미디어 매체를 장애 아동의 말 · 언어 발달 중재에 활용하기 위하여 국내외 언어치료 분야에서도 스마트폰과 태블릿 $\mathrm{PC}$ 에서 실행할 수 있는 애플리케이션을 개발하고 배포하려는 노 력이 시도되고 있다(Lee, Lee, \& Sung, 2015). 선행 연구에서 스마트 미디어 매체를 이용한 중재가 그림-단어를 활용하는 전통적 학습 방법보다 지적장애의 빠른 자동이름대기(Rapid Automatized Naming, RAN) 능력을 향상하는데 효과적이었으며(Lee, 2013), 그림만 을 제시하는 것 보다는 컴퓨터보조학습(Computer Assisted Instruction, $\mathrm{CAI})$ 을 적용하여 시각과 청각적 자극을 함께 제시했을 때 지적장애 아동의 단어재인 능력을 향상시키는데 효과적이었다 (Shin, 2003). 또한 인터넷을 활용해서 친숙한 동화를 이용한 이야 기 다시 말하기 중재는 지적장애 아동의 이야기이해력과 구문이해 력을 향상하는데 효과적이었으며(Cho, 2012), 사물 인터넷을 기반 으로 하는 스마트폰 애플리케이션을 활용한 격조사 표현 중재는 학령전기의 단순언어장애 아동에게 격조사 표현 능력을 효과적으 로 향상시켰으며 발화의 길이에도 영향을 미쳤다(Jang, 2018).

이처럼 선행 연구에서 살펴보았듯이 스마트폰이나 PC 기반 관 련 연구는 대부분 교육적 측면이나 언어중재에 국한되어 있다. 언 어중재는 아동의 언어발달을 향상시키기 위해 필요한 부분이지만 아동의 중재를 시작하기 위해서 아동의 현재 발달 수준을 파악하 고 진단 및 치료 계획을 수립, 예후를 예측하기 위해서는 언어 평가 가 매우 중요하며 이러한 평가 및 진단 과정 중 언어 검사는 필수 불 가결한 요소이다. 현재 임상에서 사용되는 언어 검사는 많은 문항 수와 종이 매체를 사용하는 검사가 주를 이루고 있다. 그로 인해 아 동의 흥미가 떨어지고 관심도가 떨어져 검사의 수행력이 좋지 않으 며 오랜 시간이 걸리기 때문에 집중력의 문제로 검사를 진행하는 데 어려움을 보이고 있다. 특히, 취학 전 언어발달지연 아동들의 경 우 시간이 길어질수록 낮은 집중력으로 검사를 수행하는 것에 어 려움을 보이는 단점이 있다. 그럼에도 불구하고, 언어발달장애 아 동을 대상으로 언어 평가나 검사 시 미디어를 달리 사용했을 때 언 어 과제의 수행 차이를 살펴본 연구는 미미하다. 최근 Kang, Park, Song, Kim 그리고 Shin (2015)의 연구에서는 증강현실 기술을 이 용하여 조음음운장애 검사 시스템을 개발하여 그 효능성을 살펴 보았으나, 조음음운장애 검사의 진행과 검 결과 저장에 필요한 기 본적인 기능에 대한 시스템만 구현하는 연구였다.
따라서, 본 연구는 이와 같은 목적을 달성하기 위하여 학령 전기 언어발달지체를 보이는 아동을 대상으로 컴퓨터 기반 REVT검사 의 타당도 연구에 앞서 기존의 그림책을 이용한 검사와 태블릿 PC 기기에 그림어휘를 탑재한 검사매체를 사용하여, 수용 및 표현 어 휘검사의 원점수, 총 문항 반응시간 및 문항별 평균 반응시간을 측 정하고, 태블릿 PC 컴퓨터 기반 검사 개발을 위한 기초 자료로 제 공하고자한다.

\section{연구방법}

\section{연구대상}

본 연구의 대상자는 생활 연령이 만 3-7세 평균 생활 연령은 만 4 세 $( \pm 11$ 개월 $)$ 로 언어치료 경력 10 년 이상의 1 급 언어재활사 1 인이 Preschool Receptve-Expressive Language Scale (PRES; Kim, Seong, $\&$ Lee, 2003) 검사결과, 언어발달지연 아동으로 진단된 아동 총 27 명(남자 18명, 여자 9 명)을 대상으로 하였다. 본 연구에 참여한 모든 아동은 언어발달지연을 제외한 다른 발달 수준은 모두 정상 발달 을 보이는 아동을 포함하였다. 또한, 본 연구에 참여한 아동은 언어 연령이나 언어지연 정도에 따라 각각 두 집단으로 나누었다. 언어발 달지연 정도는 PRES 검사 결과에 따라 통합언어 발달연령이 1 세 이상 2 세 미만의 차이를 보이는 '약간의 언어발달지체’로 간주되는 아동 집단(15명)과 2 세 이상 차이를 보여 ‘언어장애’로 간주되는 아 동 집단(12명)으로 구분하였다. 또한, 통합언어연령에 따른 집단은 PRES 검사 결과에서 통합언어연령이 '3세 이전' 아동 집단(15명)과 '3세 이후' 아동 집단(12명)으로 구분하였다.

통합언어연령은 취학 전 아동의 수용언어 및 표현언어 발달척도 (PRES) 검사 결과에서 수용언어와 표현언어 발달 연령의 평균 연령 으로 수용언어, 표현언어 연령의 합을 2 로 나눈 연령이다.

본 연구에서는 통합언어연령을 3 세 기준으로 두 집단 구성을 하 였는데, 집단의 기준인 3 세는 영아기를 지나서 유아기에 접어드는 관문이며, 이 시기에는 유아교육기관에 본격적으로 다니게 되는 첫 연령에 해당하고(Song, 2003), 이전과 비교하면 상호작용의 대상이 확대되며 사회적인 상호작용이 활발해져 언어발달이 촉진하게 되 는 변화가 나타난다. 대화에서 사용되어지는 어휘의 양이 늘어 한 단어나 두 단어보다는 문장수준으로 발전하게 되는 시기이기 때문 에(Kim \& Lee, 2007). 본 연구에서는 언어발달연령을 3 세 기준으 로 구분하여 낮은 언어연령과 높은 언어연령에서 매체의 효과에 대 해 살펴보고자 하였다. 


\section{검사도구 및 실험절차}

본 연구에서는 종이 인쇄물의 전통적인 검사와 동시에 그림 자료 를 스캔하여 Portable Document Format (PDF) 파일로 작업 후 밀 어서 넘기는 방식으로 컴퓨터 기반(태블릿 PC) 검사를 실시하였다. 본 연구에서는 스마트 미디어 매체 중 태블릿 PC가 큰 화면으로 그 림을 제시하였을 때 아동들이 보기에 편리하고 사용하는 방법이 간편하여 태블릿 $\mathrm{PC}$ 를 선정하였다. 대상자에게 취학 전 아동의 PRES 검사를 먼저 실시하였고 잠깐의 휴식시간을 가진 후 REVT 를 실시하였다. REVT는 컴퓨터 기반(태블릿 PC)과 종이 기반 검사 모두를 실시하였고 두 가지 매체로 실시하므로 학습효과가 미칠 영 향을 고려해서 처음 검사와 두 번째 검사는 일주일의 시간을 두고 무선배치로 이루어졌다. 먼저, 첫 번째는 14 명의 언어발달장애아동 에게 컴퓨터 기반 검사를 나머지 13 명의 언어발달장애아동에게 종 이 기반 검사로 나누어 실시하였으며, 일주일 뒤 방문하였을 때 첫 번째 컴퓨터 기반 검사를 받은 아동 14 명은 종이 기반 검사를, 종이
기반 검사를 받았던 13 명의 아동에게는 컴퓨터 기반 검사를 실시 하였다. REVT에 대한 매체의 영향을 알아보기 위해 그림 자료를 제시하는 매체를 제외하고는 모든 조건을 통일 시켰으며 문항별 지 시 사항은 검사 도구의 지침서에 제시된 매뉴얼대로 수행을 하여 검사 시 상호작용을 최소화하였다.

본 연구에서 사용한 측정 변수는 세 가지로 원점수, 총 반응시간, 문항별 평균 반응시간이다. 먼저, 아동의 수행력을 규준과 비교하 고 수치로 나타낼 수 있는 원점수를 측정하였고 기초선부터 최고 한계선까지 정반응 문항 당 1 점으로 채점하였다. 본 연구에서는 매 체의 효과를 알아보기 위해 두 가지의 반응시간을 측정하였는데, 총 반응시간은 검사시간의 효율성을 검사하기 위하여 측정하였으 며, 각 문항에 대한 아동의 반응시간은 매체에 대한 집중력이나 반 응성을 알아보기 위해 측정하였다. 총 반응 시간은 컴퓨터 기반(태 블릿 PC) 검사와 종이 기반 검사 각각 REVT의 전체적인 수행력 비 교를 위해 시작 문항에 따라 검사자가 그림을 제시하고 질문을 시

Table 1. Comparison of diagnostic evaluation results based on raw scores in receptive vocabulary test between paper-based vs. tablet-based test

\begin{tabular}{|c|c|c|c|c|}
\hline \multirow{2}{*}{ Participants } & \multicolumn{2}{|c|}{ Paper-based } & \multicolumn{2}{|c|}{ Tablet-based } \\
\hline & Raw score & Diagnostic evaluation & Raw score & Diagnostic evaluation \\
\hline 1 & 19 & -1 SD -2 SD (LDD) & 24 & -1 SD M (WNL) \\
\hline 2 & 16 & -1 SD -2 SD (LDD) & 26 & -1 SD M (WNL) \\
\hline 3 & 7 & Less than-2 SD (LD) & 12 & Less than-2 SD (LD) \\
\hline 4 & 24 & -1 SD M (WNL) & 27 & -1 SD M (WNL) \\
\hline 5 & 11 & Less than-2 SD (LD) & 26 & $-1 \mathrm{SD} M(\mathrm{WNL})$ \\
\hline 6 & 12 & Less than-2 SD (LD) & 13 & Less than-2 SD (LD) \\
\hline 7 & 20 & -1 SD -2 SD (LDD) & 27 & -1 SD -2 SD (LDD) \\
\hline 8 & 27 & -1 SD -2 SD (LDD) & 34 & -1 SD -2 SD (LDD) \\
\hline 9 & 55 & -1 SD M (WNL) & 52 & -1 SD M (WNL) \\
\hline 10 & 33 & Less than-2 SD (LD) & 38 & Less than-2 SD (LD) \\
\hline 11 & 70 & -1 SD M (WNL) & 75 & -1 SD M (WNL) \\
\hline 12 & 32 & Less than-2 SD (LD) & 45 & -1 SD -2 SD (LDD) \\
\hline 13 & 42 & Less than-2 SD (LD) & 53 & Less than-2 SD (LD) \\
\hline 14 & 43 & -1 SD M (WNL) & 50 & -1 SD M (WNL) \\
\hline 15 & 45 & -1 SD M (WNL) & 51 & -1 SD M (WNL) \\
\hline 16 & 44 & Less than-2 SD (LD) & 57 & -1 SD -2 SD (LDD) \\
\hline 17 & 66 & -1 SD M (WNL) & 66 & -1 SD M (WNL) \\
\hline 18 & 45 & Less than-2 SD (LD) & 42 & Less than-2 SD (LD) \\
\hline 19 & 14 & -1 SD -2 SD (LDD) & 11 & Less than-2 SD (LD) \\
\hline 20 & 6 & Less than-2 SD (LD) & 7 & Less than-2 SD (LD) \\
\hline 21 & 3 & Less than-2 SD (LD)) & 10 & Less than-2 SD (LD) \\
\hline 22 & 24 & -1 SD -2 SD (LDD) & 24 & -1 SD -2 SD (LDD) \\
\hline 23 & 2 & Less than-2 SD (LD) & 11 & Less than-2 SD (LD) \\
\hline 24 & 14 & Less than-2 SD (LD) & 15 & Less than-2 SD (LD) \\
\hline 25 & 2 & Less than-2 SD (LD) & 11 & Less than-2 SD (LD) \\
\hline 26 & 17 & Less than-2 SD (LD) & 17 & Less than-2 SD (LD) \\
\hline 27 & 26 & Less than-2 SD (LD) & 67 & $-1 \mathrm{SD} M(\mathrm{WNL})$ \\
\hline
\end{tabular}


작한 시간부터 마지막 문항의 아동이 대답을 끝낸 시간까지 총 시 간으로 정의하였으며, 초(sec)단위로 측정하였다. 또한, 문항별 평균 반응시간은 문항별로 반응 시간에 대한 수행력을 비교하기 위해 문항별로 그림이 제시된 순간부터 아동이 반응을 끝낸 시간의 합/ 문항 수로 하였으며, 초(sec)단위로 측정하였다. 각각의 변수는 1 급 언어재활사 1 인이 검사 자료 중 $20 \%$ 에 해당하는 자료에 대해 녹화된 동영상을 보고 분석을 실시하였으며, 수용 어휘 원점수 $100 \%$, 표현 어휘 원점수 $100 \%$, 총 반응시간 $94 \%$, 문항별 평균 반응 시간 $93 \%$ 의 검사자 간 신뢰도를 보였다.

언어발달지연 아동의 검사 매체 유형에 따른 수용 어휘력검사의 원점수에 근거한 진단 결과는 Table 1 과 같다. 전체 연구 대상자 27 명 중 진단 분류의 변화가 있는 연구 대상자는 7명으로 $25.93 \%$ 였다.

한편, 검사 매체 간 표현 어휘력검사의 원점수에 따른 진단 결과 는 Table 2 와 같다. 전체 연구 대상자 27명 중 진단 분류의 변화가 있는 연구 대상자는 5 명으로 $18.52 \%$ 로 나타났다.

\section{통계분석}

통계프로그램은 SPSS Statistics version 22를 사용하였으며, 언 어발달지연 정도에 따른 집단과 검사 매체를 비교하기 위해 집단 간 요인('언어발달지체' vs. '언어장애')과 집단 내 요인(컴퓨터 기반 vs. 종이 기반)의 이원혼합 분산분석(Two way mixed-ANOVA)을 실시하였다. 또한, 통합언어연령에 따른 집단과 검사 매체를 비교 하기 위해 집단 간 요인('3세 이전' vs. '3세 이후'), 집단 내 요인(컴 퓨터 기반 vs. 종이 기반)의 이원혼합 분산분석을 실시하였다. Mauchly의 구형성 검정에 의해 구형성 가정을 충족하는 경우에는 개체 내 효과 검정을 사용하였으며, Mauchly의 구형성 가정을 충 족하지 않는 경우에는 Greenhouse-Geisser로 수정된 자유도와 $F$ 값을 사용하여 분석하였고 통계적 유의수준은 .05수준에서 검정 하였다.

Table 2. Comparison of diagnostic evaluation results based on raw scores in expressive vocabulary test between paper-based vs. tablet-based test

\begin{tabular}{|c|c|c|c|c|}
\hline \multirow{2}{*}{ Participants } & \multicolumn{2}{|c|}{ Paper-based } & \multicolumn{2}{|c|}{ Tablet-based } \\
\hline & Raw score & Diagnostic evaluation & Raw score & Diagnostic evaluation \\
\hline 1 & 27 & -1 SD -2 SD (LDD) & 21 & -1 SD -2 SD (LDD) \\
\hline 2 & 2 & Less than-2 SD (LD) & 3 & Less than-2 SD (LD) \\
\hline 3 & 4 & Less than-2 SD (LD) & 4 & Less than-2 SD (LD)) \\
\hline 4 & 27 & -1 SD -2 SD (LDD) & 29 & -1 SD -2 SD (LDD) \\
\hline 5 & 4 & Less than-2 SD (LD) & 9 & Less than-2 SD (LD) \\
\hline 6 & 14 & Less than-2 SD (LD) & 14 & Less than-2 SD (LD) \\
\hline 7 & 20 & Less than-2 SD (LD) & 20 & Less than-2 SD (LD) \\
\hline 8 & 43 & -1 SD -2 SD (LDD) & 47 & -1 SD M (WNL) \\
\hline 9 & 62 & $-1 \mathrm{SD} M(\mathrm{WNL})$ & 62 & -1 SD M (WNL) \\
\hline 10 & 30 & Less than-2 SD (LD) & 43 & Less than-2 SD (LD) \\
\hline 11 & 79 & -1 SD M (WNL) & 83 & $-1 \mathrm{SD} M(\mathrm{MNL})$ \\
\hline 12 & 35 & Less than-2 SD (LD) & 44 & Less than-2 SD (LD) \\
\hline 13 & 41 & Less than-2 SD (LD) & 60 & -1 SD -2 SD (LDD) \\
\hline 14 & 44 & -1 SD -2 SD (LDD) & 48 & -1 SD M (WNL) \\
\hline 15 & 53 & -1 SD M (WNL) & 54 & -1 SD M (WNL) \\
\hline 16 & 43 & Less than-2 SD (LD) & 53 & Less than-2 SD (LD) \\
\hline 17 & 65 & -1 SD -2 SD (LDD) & 70 & -1 SD M (WNL) \\
\hline 18 & 51 & Less than-2 SD (LD) & 59 & Less than-2 SD (LD) \\
\hline 19 & 2 & Less than-2 SD (LD) & 4 & Less than-2 SD (LD) \\
\hline 20 & 3 & Less than-2 SD (LD) & 3 & Less than-2 SD (LD) \\
\hline 21 & 2 & Less than-2 SD (LD) & 2 & Less than-2 SD (LD) \\
\hline 22 & 26 & Less than-2 SD (LD) & 27 & Less than-2 SD (LD) \\
\hline 23 & 2 & Less than-2 SD (LD) & 2 & Less than-2 SD (LD) \\
\hline 24 & 22 & Less than-2 SD (LD) & 22 & Less than-2 SD (LD) \\
\hline 25 & 3 & Less than-2 SD (LD) & 3 & Less than-2 SD (LD) \\
\hline 26 & 19 & Less than-2 SD (LD) & 18 & Less than-2 SD (LD) \\
\hline 27 & 56 & -1 SD -2 SD (LDD) & 64 & -1 SD M (WNL) \\
\hline
\end{tabular}




\section{연구결과}

\section{언어발달지연 정도(‘언어발달지체’ vs. ‘언어장애’)에 따른} 검사 매체 간(컴퓨터 기반 vs. 종이 기반) 수행력 차이

수용 어휘력검사에서 언어발달지연 정도와 검사 매체 간 어휘 원 점수, 검사 매체 간 총 반응시간 및 검사 매체 간 문항별 평균 반응 시간의 평균과 표준편차는 Table 3 과 같다. 언어발달지연 정도에

Table 3. Means and standard deviations of receptive vocabulary raw scores (RS), total response time (TRT), and mean item response time (MIRT) for media type (paper vs. tablet) and group (LDD vs. LD) in receptive vocabulary test

\begin{tabular}{llrrrrr}
\hline \multirow{2}{*}{ Measures } & \multirow{2}{*}{ Media type } & \multicolumn{2}{c}{$\mathrm{LDD}(\mathrm{N}=15)$} & & \multicolumn{2}{c}{$\mathrm{LD}(\mathrm{N}=12)$} \\
\cline { 3 - 4 } \cline { 6 - 7 } & & \multicolumn{1}{c}{$\mathrm{M}$} & $\mathrm{SD}$ & & $\mathrm{M}$ & $\mathrm{SD}$ \\
\hline Raw score & Paper-based & 30.40 & 17.87 & & 21.92 & 20.31 \\
& Tablet-based & 36.87 & 17.27 & & 28.17 & 23.24 \\
Total response time & Paper-based & 293.73 & 123.37 & & 280.76 & 165.68 \\
(sec) & Tablet-based & 238.03 & 79.58 & & 228.21 & 89.39 \\
Mean item response & Paper-based & 4.16 & 2.27 & & 5.40 & 4.84 \\
time (sec) & Tablet-based & 3.79 & 2.18 & & 4.28 & 1.65 \\
\hline
\end{tabular}

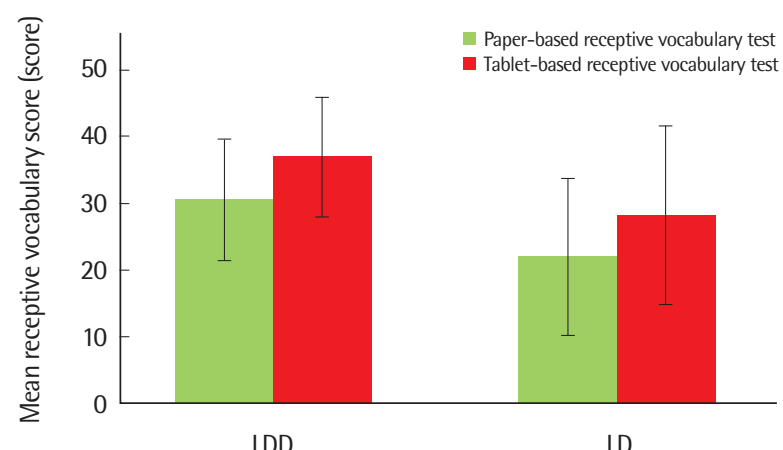

따라 매체 간 어휘 원점수를 비교하기 위하여 이원혼합 분산분석 을 실시한 결과, 언어발달지연 정도와 매체 효과 간 상호작용은 통 계적으로 유의하지 않았다 $\left(F_{(1,25)}=.004, p=.949\right)$. 검사 매체 간(컴 퓨터 기반 vs. 종이 기반) 어휘 원점수를 비교한 결과, 통계적으로 유의한 차이를 보였다 $\left(F_{(1,25)}=14.171, p=.001\right)$ (Figure 1). 언어발달 지연 정도(‘언어발달지체’ vs. ‘언어장애’)에 따라 어휘 원점수를 비 교한 결과, 통계적으로 유의한 차이를 보이지 않았다 $\left(F_{(1,25)}=1.355\right.$, $p=.255$ )(Figure 1).

언어발달지연 정도와 매체의 주효과를 살펴 보기 위하여 총 반 응시간을 비교하였다. 이원혼합 분산분석을 실시한 결과, 언어발달 지연 정도와 매체 효과 간 상호작용은 통계적으로 유의하지 않았다 $\left(F_{(1,25)}=.004, p=.951\right)$. 검사 매체 간(컴퓨터 기반 vs. 종이 기반) 총 반응시간을 비교한 결과, 통계적으로 유의한 차이를 보였다 $\left(F_{(1,25)}=\right.$ $4.573, p=.042$ ). 언어발달지연 정도('언어발달지체’ vs. ‘언어장애’) 에 따라 총 반응시간을 비교한 결과, 통계적으로 유의한 차이를 보 이지 않았다 $\left(F_{(1,25)}=.091, p=.766\right)$ (Figure 2).

언어발달지연 정도에 따라 매체 간 문항별 평균 반응시간을 비 교하기 위하여 이원혼합 분산분석을 실시한 결과, 언어발달지연 정

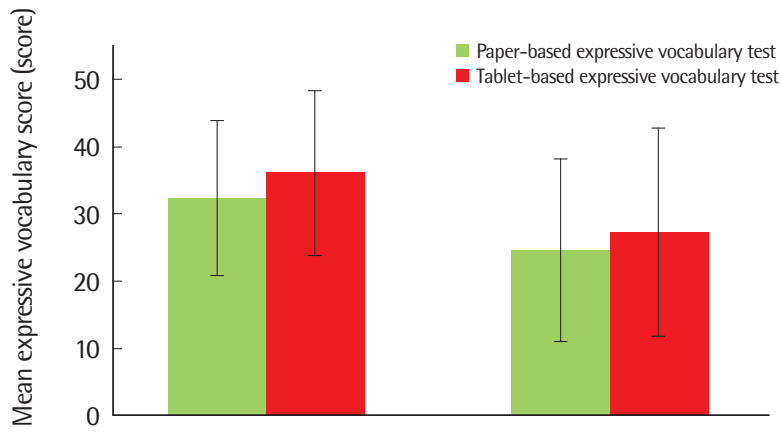

LDD

Figure 1. Comparison of mean receptive and expressive vocabulary scores in receptive and expressive vocabulary test (REVT) according to language development severity (Language development delay (LDD) vs. Language disorders (LD)) and media type (paper vs. tablet).

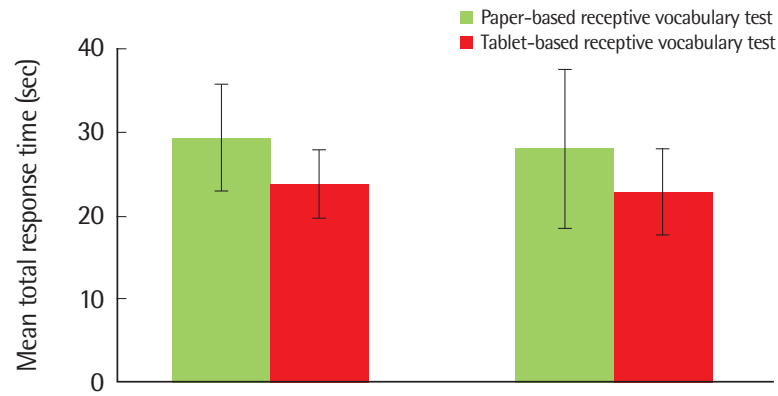

LDD

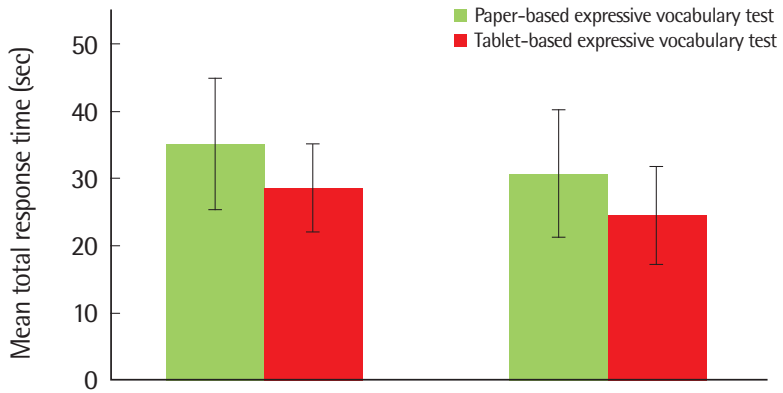

LDD
LD

Figure 2. Comparison of total response time in receptive and expressive vocabulary test (REVT) according to language development severity (Language development delay (LDD) vs. Language disorders (LD)) and media type (paper vs. tablet). 
도와 매체 효과간 상호작용은 통계적으로 유의하지 않았다 $\left(F_{(1,25)}=\right.$ $.383, p=.541)$. 검사 매체 간(컴퓨터 기반 vs. 종이 기반) 문항별 평 균 반응시간을 비교한 결과, 통계적으로 유의한 차이를 보이지 않 았고 $\left(F_{(1,25)}=1.500, p=.232\right)$, 언어발달지연 정도('언어발달지체' vs. ‘언어장애')에 따라 문항별 평균 반응시간을 비교한 결과, 통계적으 로 유의한 차이를 보이지 않았다 $\left(F_{(1,25)}=.831, p=.371\right)$ (Figure 3).

한편, 표현 어휘력검사에서 언어발달지연 정도와 검사 매체 간 어휘 원점수, 검사 매체 간 총 반응시간 및 검사 매체 간 문항별 평 균 반응시간의 평균과 표준편차는 Table 4 와 같다. 언어발달지연 정도에 따라 매체 간 어휘 원점수를 비교하기 위하여 이원혼합 분 산분석을 실시한 결과, 언어발달지연 정도와 매체 효과 간 상호작 용은 통계적으로 유의하지 않았다 $\left(F_{(1,25)}=.235, p=.632\right)$. 검사 매 체 간(컴퓨터 기반 vs. 종이 기반) 어휘 원점수를 비교한 결과, 통계 적으로 유의한 차이를 보였으나 $\left(F_{(1,25)}=10.224, p=.004\right.$ ) (Figure 1), 언어발달지연 정도('언어발달지체' vs. '언어장애')에 따라 어휘 원 점수를 비교한 결과, 통계적으로 유의한차이를 보이지 않았다 $\left(F_{(1,25)}=\right.$ $.805, p=.378)$.
언어발달지연 정도에 따라 매체 간 총 반응시간을 비교하기 위하 여 이원혼합 분산분석을 실시한 결과, 언어발달지연 정도와 매체 효과 간 상호작용은 통계적으로 유의하지 않았다 $\left(F_{(1,25)}=.005\right.$, $p=.943)$. 검사 매체 간(컴퓨터 기반 vs. 종이 기반) 총 반응시간을 비교한 결과, 통계적으로 유의한 차이를 보인 반면 $\left(F_{(1,25)}=9.161\right.$, $p=.006$ ), 언어발달지연 정도('언어발달지체' vs. '언어장애')에 따 라 총 반응시간을 비교한 결과, 통계적으로 유의한 차이를 보이지 않았다 $\left(F_{(1,25)}=.572, p=.457\right)$ (Figure 2).

언어발달지연 정도에 따라 매체 간 문항별 평균 반응시간을 비 교하기 위하여 이원혼합 분산분석을 실시한 결과, 언어발달지연 정 도와 매체 효과 간 상호작용은 통계적으로 유의하지 않았다 $\left(F_{(1,25)}=\right.$ $.445, p=.511)$. 검사 매체 간(컴퓨터 기반 vs. 종이 기반) 문항별 평균 반응시간을 비교한 결과, 통계적으로 유의한 차이를 보였고 $\left(F_{(1,25)}=\right.$ $6.667, p=.016)$, 언어발달지연 정도('언어발달지체' vs. '언어장애') 에 따라 문항별 평균 반응시간을 비교한 결과, 통계적으로 유의한 차이를 보이지 않았다 $\left(F_{(1,25)}=1.523, p=.229\right)$ (Figure 3 ).
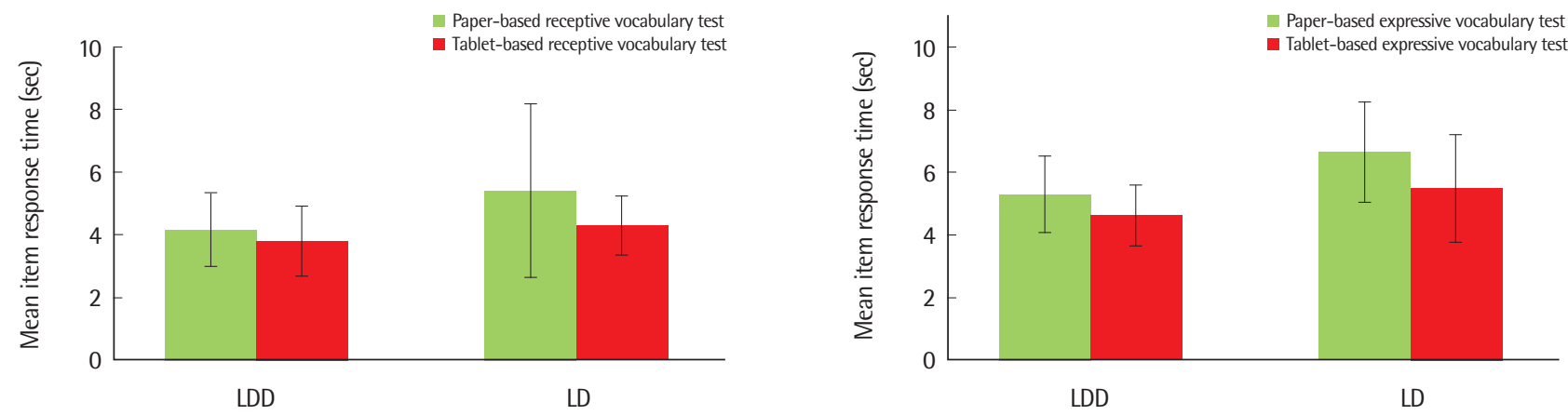

Figure 3. Comparison of average response time per question in receptive and expressive vocabulary test (REVT) according to language development severity (Language development delay (LDD) vs. Language disorders (LD)) and media type (paper vs. tablet).

Table 4. Means and standard deviations of expressive vocabulary raw scores (RS), total response time (TRT), and mean item response time (MIRT) for media type (paper vs. tablet) and group (LDD vs. LD) in expressive vocabulary test

\begin{tabular}{llrrrrr}
\hline \multirow{2}{*}{ Measures } & \multirow{2}{*}{ Media type } & \multicolumn{2}{c}{$\mathrm{LDD}(\mathrm{N}=15)$} & & \multicolumn{2}{c}{$\mathrm{LD}(\mathrm{N}=12)$} \\
\cline { 7 - 8 } \cline { 6 - 7 } & & $\mathrm{M}$ & $\mathrm{SD}$ & & $\mathrm{M}$ & $\mathrm{SD}$ \\
\hline Raw score & Paper-based & 32.33 & 22.19 & & 24.5 & 23.66 \\
& Tablet-based & 36.07 & 23.93 & & 27.25 & 26.89 \\
Total response time & Paper-based & 293.73 & 123.37 & & 280.76 & 165.68 \\
(sec) & Tablet-based & 238.03 & 79.58 & & 228.21 & 89.39 \\
Mean item response & Paper-based & 350.32 & 188.47 & & 306.54 & 163.03 \\
time (sec) & Tablet-based & 285.69 & 126.64 & & 244.94 & 125.2 \\
\hline
\end{tabular}

Table 5. Comparison of receptive vocabulary raw scores (RS), total response time (TRT), and mean item response time (MIRT) according to integrated language age and media type in receptive vocabulary test

\begin{tabular}{|c|c|c|c|c|c|}
\hline \multirow[t]{2}{*}{ Measures } & \multirow[t]{2}{*}{ Media type } & \multicolumn{2}{|c|}{$\begin{array}{l}\text { Before } 3 \text { years } \\
\quad(N=15)\end{array}$} & \multicolumn{2}{|c|}{$\begin{array}{l}\text { After } 3 \text { years } \\
\qquad(\mathrm{N}=12)\end{array}$} \\
\hline & & $M$ & SD & $M$ & SD \\
\hline \multirow[t]{2}{*}{ Raw score } & Paper-based & 12.73 & 7.49 & 44.00 & 14.03 \\
\hline & Tablet-based & 17.40 & 7.37 & 52.50 & 12.24 \\
\hline \multirow{2}{*}{$\begin{array}{l}\text { Total response time } \\
\text { (sec) }\end{array}$} & Paper-based & 293.73 & 123.37 & 280.76 & 165.68 \\
\hline & Tablet-based & 238.03 & 79.58 & 228.21 & 89.39 \\
\hline \multirow{2}{*}{$\begin{array}{l}\text { Mean item response } \\
\text { time (sec) }\end{array}$} & Paper-based & 256.54 & 154.04 & 327.25 & 117.01 \\
\hline & Tablet-based & 220.75 & 85.30 & 249.81 & 79.60 \\
\hline
\end{tabular}




\section{통합언어연령(‘3세 이전’ vs. ‘3세 이후’)에 따른 검사 매체 간(컴퓨터 기반 vs. 종이 기반) 수행력 차이}

수용 어휘력검사에서 통합언어연령과 검사 매체 간 어휘 원점수, 검사 매체 간 총 반응시간, 검사 매체 간 문항별 평균 반응시간의 평 균과 표준편차는 Table 5 와 같다. 통합언어연령에 따라 매체 간 어 휘 원점수를 비교하기 위하여 이원혼합 분산분석을 실시한 결과, 통합언어연령과 매체 효과 간 상호작용은 통계적으로 유의하지 않 았다 $\left(F_{(1,25)}=1.357, p=.255\right)$. 검사 매체 간(컴퓨터 기반 vs. 종이 기 반) 어휘 원점수를 비교한 결과, 통계적으로 유의한 차이를 보였으 며 $\left(F_{(1,25)}=16.013, p=.000\right)$, 통합언어연령에 따라('3세 이전' vs. '3 세 이후’) 어휘 원점수를 비교한 결과, 통계적으로 유의한 차이를 보 였다 $\left(F_{(1,25)}=82.383, p=.000\right)$.

통합언어연령에 따라 매체 간 총 반응시간을 비교하기 위하여 이 원혼합 분산분석을 실시한 결과, 통합언어연령과 매체 효과 간 상 호작용은 통계적으로 유의하지 않았다 $\left(F_{(1,25)}=.696, p=.412\right)$. 검사 매체 간(컴퓨터 기반 vs. 종이 기반) 총 반응시간을 비교한 결과, 통 계적으로 유의한 차이를 보였으나 $\left(F_{(1,25)}=5.142, p=.032\right)$, 통합언 어연령에 따라(‘3세 이전' vs. ‘3세 이후) 총 반응시간을 비교한 결과, 통계적으로 유의한 차이를 보이지 않았다 $\left(F_{(1,25)}=1.857, p=.185\right)$.

통합언어연령에 따라 매체 간 문항별 평균 반응시간을 비교하기 위하여 이원혼합 분산분석을 실시한 결과, 통합언어연령과 매체 효과 간 상호작용은 통계적으로 유의하지 않았다 $\left(F_{(1,25)}=.988\right.$, $p=.330$ ). 검사 매체 간(컴퓨터 기반 vs. 종이 기반) 문항별 평균 반 응시간을 비교한 결과, 통계적으로 유의한 차이를 보이지 않았고 $\left(F_{(1,25)}=1.122, p=.300\right)$, 통합언어연령에 따라('3세 이전' vs. '3세 이 후') 문항별 평균 반응시간을 비교한 결과, 통계적으로 유의한 차이 를 보이지 않았다 $\left(F_{(1,25)}=1.270, p=.271\right)$.

표현 어휘력검사에서 통합언어연령과 검사 매체 간 어휘 원점수, 검사 매체 간 총 반응시간, 문항별 평균 반응시간의 평균과 표준편

Table 6. Comparison of expressive vocabulary raw scores (RS), total response time (TRT), and mean item response time (MIRT) according to integrated language age and media type in expressive vocabulary test

\begin{tabular}{|c|c|c|c|c|c|}
\hline \multirow[t]{2}{*}{ Measures } & \multirow[t]{2}{*}{ Media type } & \multicolumn{2}{|c|}{$\begin{array}{l}\text { Before } 3 \text { years } \\
\qquad(\mathrm{N}=15)\end{array}$} & \multicolumn{2}{|c|}{$\begin{array}{c}\text { After } 3 \text { years } \\
\quad(\mathrm{N}=12)\end{array}$} \\
\hline & & M & SD & M & SD \\
\hline \multirow[t]{2}{*}{ Raw score } & Paper-based & 11.80 & 10.53 & 50.17 & 13.80 \\
\hline & Tablet-based & 12.07 & 9.92 & 57.25 & 11.69 \\
\hline \multirow{2}{*}{$\begin{array}{l}\text { Total response time } \\
\text { (sec) }\end{array}$} & Paper-based & 293.73 & 123.37 & 280.76 & 165.68 \\
\hline & Tablet-based & 238.03 & 79.58 & 228.21 & 89.39 \\
\hline \multirow{2}{*}{$\begin{array}{l}\text { Mean item response } \\
\text { time (sec) }\end{array}$} & Paper-based & 240.76 & 151.67 & 443.48 & 136.99 \\
\hline & Tablet-based & 201.73 & 115.39 & 349.89 & 82.73 \\
\hline
\end{tabular}

차는 Table 6과 같다.

통합언어연령에 따라 매체 간 어휘 원점수를 비교하기 위하여 이 원혼합 분산분석을 실시한 결과, 통합언어연령과 매체 효과 간 상호 작용은 통계적으로 유의한 차이를 보였다 $\left(F_{(1,25)}=20.281, p=.000\right)$.

통합언어연령과 매체 효과 간 상호작용으로 통합언어연령 내 검 사 매체의 어휘 원점수를 비교하기 위하여 대응표본 $t$-검정을 실시 한 결과, 통합언어연령이 ‘3세 이전’은 통계적으로 유의한 차이를 보 이지 않았으나 $(t=-.459, p=.653)$, 통합언어연령이 '3세 이후’는 통 계적으로 유의한 차이를 보였다 $(t=-4.615, p=.001)$.

통합언어연령에 따라 매체 간 총 반응시간을 비교하기 위하여 이 원혼합 분산분석을 실시한 결과, 통합언어연령과 매체 효과 간 상 호작용은 통계적으로 유의하지 않았다 $\left(F_{(1,25)}=1.838, p=.187\right)$. 검 사 매체 간(컴퓨터 기반 vs. 종이 기반) 총 반응시간을 비교한 결과, 통계적으로 유의한 차이를 보였고 $\left(F_{(1,25)}=10.854, p=.003\right)$, 통합언 어연령에 따라(‘3세 이전' vs. '3세 이후’) 총 반응시간을 비교한 결 과, 통계적으로 유의한 차이를 보였다 $\left(F_{(1,25)}=15.660, p=.001\right)$.

통합언어연령에 따라 매체 간 문항별 평균 반응시간을 비교하기 위하여 이원혼합 분산분석을 실시한 결과, 통합언어연령과 매체 효과 간 상호작용은 통계적으로 유의하지 않았다 $\left(F_{(1,25)}=.141\right.$, $p=.711)$. 검사 매체 간(컴퓨터 기반 vs. 종이 기반) 문항별 평균 반 응시간을 비교한 결과, 통계적으로 유의한 차이를 보였고 $\left(F_{(1,25)}=\right.$ $6.008, p=.022$ ), 통합언어연령에 따라('3세 이전' vs. '3세 이후') 문 항별 평균 반응시간을 비교한 결과, 통계적으로 유의한 차이를 보 였다 $\left(F_{(1,25)}=11.995, p=.002\right)$.

\section{논의 및 결론}

본 연구에서는 컴퓨터 기반(태블릿 PC) 검사와 종이 기반 검사 가 REVT에서 검사 매체의 변화가 언어발달지연 아동의 검사 수행 력에 영향을 미치는지 알아보기 위해서 생활 연령이 만 3-7세인 언 어발달지연을 보이는 아동 27 명을 대상으로 언어발달지연 정도의 중증도와 통합언어연령에 따라 검사 매체 간 수행력을 비교 분석 하였다.

REVT는 영유아기부터 성인기까지 우리말의 수용 및 표현어휘 력을 진단할 수 있는 표준화된 검사도구로 문어 자료를 중심으로 언어발달순서에 근거하여 문항에 적합한 연령대를 고려하여 개발 되었으며, 그림 자료를 사용한 어휘력 검사 도구이다(Kim, Hong, \& Kim, 2009). REVT는 피검사자가 4 개의 그림 자료 중 목표 어휘 를 나타내는 그림을 지적하거나, 제시되는 그림을 보고 목표 어휘 를 산출하도록 유도하는 방법으로 실시한다. 이러한 방법의 특성 
상 총 문항 반응 시간과 평균 문항별 반응시간은 검사에 대한 아동 의 집중력이나지루함의 정도를 예측할 수 있다.

본 연구에서 언어발달지연 정도의 중증도('언어발달지체' vs. '언 어장애’)에 따른 컴퓨터 기반(태블릿 PC) 검사와 종이 기반 검사간 REVT중 수용어휘력 검사의 수행력 차이를 살펴본 결과, 검사 매 체에 따라 수행력의 차이를 보였으며, 언어발달지연 정도의 중증도 는 수행력에 차이를 보이지 않았다. 검사 매체의 효과에서는 수용 어휘력검사의 문항별 평균 반응시간을 제외하고 컴퓨터 기반(태블 릿 $\mathrm{PC}$ )에서 원점수, 총 반응시간, 문항별 평균 반응시간에서 통계 적으로 유의하게 더 좋은 수행력을 보였다. 즉, 컴퓨터 기반 검사에 서 언어발달지체아동군과 언어발달장애아동군 모두 원점수가 더 유의하게 높게 나타났으며, 총 반응시간에서 두 집단 모두 통계적 으로 유의하게 더 짧은 시간이 소요되었다. 이러한 결과는 검사를 진행할 때 수용 어휘력검사에서 제시된 4 개의 그림을 보고 치료사 가 이야기하는 그림을 지적하는 방식으로 실시하는데, 언어발달에 문제를 보이는 아동 집단에서 중증도에 상관없이 컴퓨터 기반(태 블릿 PC) 매체에 대한 높은 흥미와 집중으로 인해 검사 전체 시간 뿐 아니라 문항별 반응 시간도 짧게 소요되었으며, 이는 빠른 시간 내에 검사를 마친 결과로 여겨진다. 흥미로운 것은 검사 시간뿐 아 니라 어휘 원점수의 변화로 인해 어휘 발달의 진단 결과의 변화가 있었으며, 수용 어휘는 전체 연구 대상자 중 $25.93 \%$ 로 본 언어발달 지연 아동 참여자 중 약 $1 / 3$ 에 해당하는 아동 7 명이 수용 어휘 진단 결과의 변화를 보였다. 특히, $22.22 \%$ 는 어휘능력 발달지체에서 유 의요망이나 정상발달로, 유의요망에서 정상 발달범주로 바뀌는 경 우도 $7.40 \%$ 였으나, 대상자 중 1 명만이 반대로 유의요망에서 어휘능 력 발달지체로 더 나쁜 수행력을 보였다. 이 아동의 경우, 부모의 보 고에 의하면, 평소 스마트폰이나 태블릿 PC 등 미디어에 노출이 적 다고 하였는데, 이로 인해 다른 대상자보다 낮은 관심도와 흥미로 생긴 결과라고 유추할 수 있겠다.

한편, 표현 어휘의 경우에도 매체에 따라 원점수, 총 반응시간, 문 항별 평균 반응시간이 유의미한 차이가 있었으며, 언어발달지연 정 도의 중증도에 따라서는 유의미한 차이는 보이지 않았다. 표현 어 휘의 경우도 어휘 발달의 진단 결과 변화가 있었고 전체 연구 대상 자의 5 명인 $18.52 \%$ 가 표현 어휘 진단 결과 변화를 보였다. 이는 태 블릿 $\mathrm{PC}$ 를 사용하여 검사한 경우 대부분 유의요망에서 정상발달 범주로 좋아지는 경우였다. 따라서, 이러한 결과는 컴퓨터 기반(태 블릿 PC) 매체를 검사에서 사용하였을 때 선행 연구에서와 같이 집중이나 흥미를 유발하여 검사 상황에서 긍정적 태도로 인해 언 어 수행력을 높이는 것으로 여겨진다.

통합언어연령에 따른('3세 이전' vs. '3세 이후’) 검사 매체 간(컴
퓨터 기반 vs. 종이 기반) REVT의 언어 수행력 차이를 살펴본 결과, 수용 어휘력검사에서는 검사 매체에 따라 원점수, 총 반응시간에 유의한 차이를 보였다. 즉, 컴퓨터 기반 검사에서 통합언어연령 3세 이전 집단과 3 세 이후 집단 모두 원점수가 유의하게 높게 나타났으 며, 총 반응시간도 두 집단 모두 컴퓨터 기반 (태블릿 PC)에서 유의 하게 더 짧은 시간이 소요되었고 문항별 반응시간은 두 집단 모두 컴퓨터 기반(태블릿 PC)에서 짧은 시간이 소요되었지만 유의한 차 이는 보이지 않았다.

또한, 통합언어연령에 따라 3 세 이전과 3 세 이후 집단 간 원점수 가 유의한 차이를 보였으며, 3세 이후 집단이 유의하게 높게 나타났 다. REVT의 최고한계선은 8 개 중 6 개 문항이 틀려야 하고 검사를 종료하게 되는데 통합언어연령이 높아질수록 더 문항을 계속해서 맞추다 보면 통합언어연령이 낮은 집단에 비해 검사시간이 길어질 수 있다. 본 연구 결과에서도 이와 같은 이유로 3 세 이후 집단이 좀 더 길어졌으나 유의미한 차이는 없었으며, 문항별 평균 반응시간도 3 세 이후가 더 짧았으나 유의미한 차이는 보이지 않았다.

표현 어휘의 경우, 검사 매체에 따라 원점수는 통합언어연령 3세 이전은 컴퓨터 기반(태블릿 PC) 매체에서 좀 더 높았으나, 유의미 한 차이는 보이지 않았으며, 통합언어연령 3세 이후는 검사 매체에 따라 특히, 컴퓨터 기반(태블릿 PC) 매체에서 유의미하게 높은 점 수를 보였다. 따라서, 표현 어휘력검사에서는 통합언어연령이 높은 집단일수록 컴퓨터 기반 검사가 어휘 원점수, 총 반응시간, 문항별 평균 반응시간에 영향을 주는 것을 의미한다. 아울러, 총 반응시간 과 문항별 평균 반응시간은 컴퓨터 기반(태블릿 PC) 매체에서 유 의하게 더 좋은 수행력을 나타내었다. 이러한 결과들은 컴퓨터 기 반(태블릿 PC) 매체가 아동의 잠재적인 능력을 끌어내어 수용 어 휘뿐 아니라 표현 어휘 수행력에 영향을 주고, 반응시간에도 영향 을 줄 수 있음을 의미하며, 컴퓨터 기반(태블릿 PC) 언어 검사가 통 합언어연령이 높은 아동일수록 흥미를 유도하고 집중력을 높임으 로써 아동의 최대 수행력을 이끌어 내는 데 도움을 줄수 있음을 시 사하였다. 특히, 본 연구에서는 통합언어연령이 3 세 이후인 집단에 서 검사 매체에 대한 영향이 유의하게 나타났으므로 이러한 점을 고려하여 통합언어연령이 높은 아동에게 컴퓨터 기반(태블릿 PC) 검사의 활용성과 접근성이 유용할 것으로 사료된다.

이상의 결과를 살펴 보았을 때, 본 연구는 임상 현장에서 언어문 제를 보이는 아동에게 태블릿 PC기반 검사의 활용 가치와 의의가 매우 크다고 할 수 있겠다. 특히, 언어발달지연이나 장애를 보이는 아동에게 임상 현장에서 컴퓨터 기반의 검사가 이루어진다면 좀 더 아동의 집중력을 유지하며, 반응시간을 줄이고 어휘 수행력을 높이는 데 도움을 줄 수 있을 것으로 사료된다. 또한, 최근 디지털 
미디어의 사용이 보편화되어 초기 아동 교육에서 사용되고 있는 실정을 고려할 때, 추후에는 임상에서 아동의 언어능력 및 잠재력 을 최대로 이끌어내기 위해 컴퓨터 기반 검사가 많이 개발되어야 할 것이다. 아직까지 국내의 언어 재활 임상 현장에서는 언어 평가 를 위한 태블릿 PC기반 검사가 개발되지는 않았지만, 본 연구의 결 과는 추후의 PC기반 언어평가 개발을 위한 기초 자료로 활용될 수 있을 것이다. 이와 더불어, 언어발달문제를 보이는 모든 아동 집단 에서 매체 유형에 따라 검사 결과가 다르게 나타나므로 검사에 사 용되는 매체에 대한 고려가 필요함을 시사하였다. 즉, 컴퓨터 기반 에서의 높은 수행력으로 인하여 언어발달지연아동의 진단 분류가 달라지는 경우도 나타났는데, 이는 종이 기반 검사의 규준을 그대 로 사용하였기 때문이다. 따라서, 태블릿 PC기반 REVT검사의 신 뢰도 및 타당도를 높이기 위해서는 컴퓨터 기반 검사 결과를 종이 기반 검사의 규준을 그대로 사용하는 것은 문제가 될 수 있으므로, 컴퓨터 기반 검사 규준에 대한 후속 연구들이 필요하며, 컴퓨터 기 반 REVT검사를 개발할 때 연령대 별로 컴퓨터 기반에 맞는 규준 점수가 마련되어야할 것이다.

Kim, Hong과 Kim (2009)은 한국 아동 및 성인의 수용어휘 및 표현어휘 능력을 측정하기 위해 REVT를 개발하고 그 신뢰도를 분 석하기 위해 1 차에서 3 차에 걸쳐 총 6,800 여 명의피험자를 대상으 로 전국단위로 표준화를 실시하여 검사도구를 개발하였다. REVT 검사 실시의 안정성을 검증하기 위해 재검사 신뢰도를 실시한 결과, 수용 및 표현 어휘력 검사는 .823 과 .855 로 비교적 높게 산출되었으 며, 검사 문항의 내적 일관성을 검증하기 위한 반분검사 신뢰도 지 수는 각각 . 884 와 .940으로 상당히 높게 나타났다. Kim과 Lee 등 (2009)은 4-6세 해당하는 언어발달지체 아동 20명과 생활연령 및 성별을 일치시킨 일반아동 20 명을 대상으로 개발중인 REVT검사 를 실시하였으며, 검사 결과 일반 아동과 언어발달지체아동 간 집 단 간 차이가 유의하게 나타났다. 본 연구에서는 언어발달지체나 장애를 보이는 아동 27 명을 대상으로 하여 기존의 종이 매체 검사 와 컴퓨터 기반 검사의 수행력만을 비교하였으므로, 추후의 연구 에서는 언어발달에 문제를 보이는 아동과 성별과 생활연령을 일치 시킨 아동 집단 간 비교를 통해 컴퓨터 기반 REVT의 타당도를 살 펴볼 필요가 있다.

본 연구의 제한점으로는 적은 수를 대상으로 중복장애가 없는 언어발달지연을 보이는 아동을 대상으로 실시하였다. 추후의 연구 에서는 좀 더 많은 수의 대상자를 포함하여 연구 결과의 타당성을 높이는 것이 필요하며, 정상아동에 있어서도 검사 매체에 따른 언 어 수행력 및 반응시간의 차이가 있는지 살펴보는 것이 필요하다. 또한, REVT검사 외에 아동의 언어발달을 평가하는 다른 언어 검
사로 확대하여 연구를 진행할 필요가 있으며, 다른 언어장애군(자 폐, 지적장애, $\mathrm{ADHD}$ 등)에게 확대하여 언어발달지연 외에 다른 언 어장애군에서도 수행력의 차이를 보이는지 비교해 볼 필요가 있다.

\section{REFERENCES}

Cho, M. K. (2012). Language intervention using internet animated fairy tale story for children with intellectual disabilities the effect of story comprehension and syntax understanding (Master's thesis). Deagu University, Gyeongsan, Korea.

Hong, G. H., Kim, Y. T., \& Kim, S. J. (2014). A Preliminary Study for Development of Screening Version of REVT for the 3 Years of Korean Children. Communication Sciences and Disorders, 19(1), 1-8.

Jang, K. E. (2018). The effect of a case marker intervention study on case marker (grammar morpheme) expression and spoken length of children with specific language disorders in preschool age by using smartphone application based on IoT (Master's thesis). Ewha Womans University, Seoul, Korea.

Jeong, M. K. (2015). Lexical representation of emotions for High function autism via story program intervention using smart media (humanoid robot vs. PC) (Master's thesis). Ewha Womans University, Seoul, Korea.

Kang, D. H., Park, H. J., Song, B. D., Kim, J. D., \& Shin, B. J. (2015). Design and development of an articulation and phonological disorder assessment system using augmented reality. Journal of Speech \& Hearing Disorders, 24(2), 87-94.

Kim, B. R. (2019). Development of computer-based neuropsychological tests using K-RBANS and comparison with pencil-and-paper tests (Master's thesis). Kyungbook National University, Daegu, Korea.

Kim, B., Park, Y. H., \& Yi, S. H. (2017). The effects of presented media types on spatial cognition task performance in preschool children. Child Studies in Asia-Pacific Contexts, 7(1), 27-38.

Kim, J. W., Bang, H. D., Shin, W. H., Kang, T. W., Gwan, M. H., \& Kim, J. H. (2011). A study on correlation between smart media efficacy and effectiveness of learning through iPad. The HCI Society of Korea, 1019-1024.

Kim, K. Y., \& Lee, S. E. (2007). Young children's executive function and peer interaction according to language abilities. Journal of Future Early Childhood Education, 14(1), 167-197.

Kim, Y. T., Hong, G. H., \& Kim, K. H. (2009). Content and reliability analyses of the Receptive and Expressive Vocabulary Test (REVT). Korean Journal of Communication \& Disorders, 14(1), 34-45.

Kim, Y. T., Hong, G. H., Kim, K. H., Jang, H. S., \& Lee, J. Y. (2009). Receptive 
\& expressive vocabulary test (REVT). Seoul: Seoul Community Rehabilitation Center.

Kim, Y. T., Lee, J. Y., Hong, K. H., Kim, K. H., \& Chang, H. S. (2009). Validity of the Receptive and Expressive Vocabulary Test on Preschool Children with Language Delay. Journal of Speech, Language, \& Hearing Disorders, 18(1), 57-72.

Kim, Y. T., Seong, T. J., \& Lee, Y. (2003). Preschool Receptive-Expressive Language Scale (PRES). Seoul: Seoul Community Rehabilitation Center.

Lee, S. H. (2013). Effects of a smart device based language training application program on reading ability of students with intellectual developmental disor$\operatorname{der}$ (Doctoral dissertation). Chonnam National University, Gwangju, Korea.

Lee, J. M., Ki, H. Y., \& Lee, J. H. (2012). Comparison study for learning efficiency improvement by using new media: Based on the same contents in different media. The HCI Society of Korea, 835-837.

Lee, J. Y., \& Kim, Y. T. (2009). A Comparative study of group and individual test results on vocabulary tests administered to teenagers. Journal of Speech ఓHearing Disorders, 18(1), 129-143.
Lee, Y. M. (2005). An analysis of the case study on tablet computer based mobile learning environment. Journal of Korean Association of Computer Education, 8(1), 25-32.

Lee, Y. M., Lee, S. B., \& Sung, M. K. (2015). Analysis of mobile application trends for speech and language therapy of children with disabilities in Korea. Phonetics and Speech Sciences, 7(3), 153-163.

Shin, M. S. (2003). The effect of word recognition for children with the mental retardation by visual and audial presentated condition in multi-media CAI (Master's thesis). Dankook University, Seoul, Koread.

Song, J. S. (2003). Effects of children's social ability, temperament, emotionality, and parenting style on children's problem behavior. Korea Journal of Child Care and Education, 35, 143-161.

Yeon, K. N. (2007). Measuring the Effectiveness of Digital-Textbook in U-Learning Environments (Master's thesis). Dongguk University, Seoul, Korea.

Yoo, K. J. (2012). A study on the development of program by using smart phones and tablet PC and its effects on scientific thinking of young children. Journal of Korea Open Association for Early Childhood Education, 17(3), 85-110. 


\section{국문초록}

\section{언어발달지연 아동의 컴퓨터 기반 검사와 종이 기반 검사의 수용 및 표현어휘 수행력 비교 박지숙 $\cdot$ 최성희 ${ }^{12} \cdot$ 이경재 ${ }^{12} \cdot$ 최철희 ${ }^{12}$ \\ '대구가톨릭대학교 의료보건산업대학원 언어청각치료학과, ${ }^{2}$ 대구가톨릭대학교 바이오메디대학 언어청각치료학과}

배경 및 목적: 본 연구는 언어발달지연 아동의 한국판 수용 - 표현 어휘력 검사에서 컴퓨터 기반(태블릿 PC) 매체와 종이 기반 매체를 이용하여 매체의 변화가 아동의 언어 수행력에 차이를 보이는지 알아보고자 하였다. 방법: 연구의 대상은 생활 연령이 만 3-7세의 언어 발달지연 아동 27 명을 대상으로 하였다. 언어발달지연 정도와 통합언어연령에 따라 각각 두 집단으로 구성하였다. 연구대상을 선정하 기 위하여 취학 전 아동의 수용언어 및 표현언어 발달척도(Preschool Receptive-Expressive language Scale) 검사를 실시하고 매체를 다 르게 하여 무작위 순서로 수용·표현 어휘력검사(REVT)를 일주일의 간격을 두고 실시하였다. 원점수, 총 반응시간, 문항별 평균 반응 시간을 측정하여 검사 매체 간 차이를 살펴 보았으며, 언어발달지연 정도와 통합언어연령에 따라 검사 매체 간 수행력에 대해 비교 분석 하였다. 결과: REVT검사 결과, 수용 및 표현 어휘 원점수 모두 종이 기반 검사보다 컴퓨터 기반 검사에서 통계적으로 유의하게 더 높은 점수가 나타났다. 한편, 언어지연 정도의 중증도에 상관없이 컴퓨터 기반 검사에서는 표현형 어휘검사에서 총 반응시간과 문항별 평균 반응시간이 통계적으로 유의미하게 짧았지만, 수용형 어휘검사에서는 총 반응시간만 현저히 짧게 나타났다. 논의 및 결론: 본 연구에 서는, 모든 언어 발달 지연 아동군에서, 검사 결과는 매체의 종류에 따라 달라졌다. 특히, 컴퓨터 기반 검사는 언어 발달 아동의 집중도 를 유지하며 반응 시간을 줄이고 어휘 성능을 향상시키는데 기여하였다. 따라서 각 매체 검사의 규준을 그대로 사용하는 것은 문제가 있을수 있으며, 검사에 사용되는 매체에 대한 고려가 필요하다.

핵심어: 언어발달지연, REVT, 언어 수행력, 총 반응시간, 문항별 평균 반응시간, 컴퓨터 기반 검사

\section{참고문헌}

강덕훈, 박희준, 송복득, 김진동, 신범주(2015). 증강현실을 이용한 조음음운장애 검사 시스템 설계 및 구현. 언어치료연구, 24(2), 87-94.

김기예, 이소은(2007). 수용언어 및 표현언어 능력에 따른 유아의 실행기능과 또래상호작용. 미래유아교육학회지, 14(1), 167-197.

김보람(2019). K-RBANS를 사용하여 컴퓨터 기반 신경심리검사의 구현과 지필 기반 검사와의 비교. 경북대학교 대학원 석사학위논문.

김영태, 성태제, 이윤경(2003). 취학 전 아동의 수용언어 및 표현언어 발달척도(Preschool Receptive-Expressive Language Scale, PRES). 서울: 서울 장애인종합복지관.

김영태, 이주연, 홍경훈, 김경희, 장혜성(2009). 수용-표현 어휘력검사(Receptive Expressive Vocabulary Test, REVT)의 타당도 연구: 취학 전 언어발 달지체아동을 중심으로. 언어치료연구, 18(1), 57-72.

김영태, 홍경훈, 김경희(2009). 수용 및 표현 어휘력 검사의 개발연구: 문항개발 및 신뢰도 분석을 중심으로. 언어청각장애연구, 14(1), 34-45.

김영태, 홍경훈, 김경희, 장혜성, 이주연(2009). 수용-표현 어휘력검사(Receptive and Expressive Vocabulary Test, REVT). 서울: 서울장애인종합복지관. 김정욱, 방현덕, 신원호, 강태우, 권미홍, 김주환(2011). 스마트 미디어 효능감과 아이패드를 통한 학습 능력간의 관련성 연구. 한국HCI학회 학술대회, 1019-1024.

송진숙(2003). 유아의 문제행동에 영향을 미치는 유아의 기질, 사회적 능력, 정서지능 및 부모의 양육 태도. 한국영유아보육학, 35, 143-161.

신명숙(2003). 멀티미디어 CAI 프로그램에서 시각과 청각 제시조건이 정신지체아의 단어재인에 미치는 영향 단국대학교 특수교육대학원 석사학위 논문.

연꽃님(2007). U-Learning 환경에서의 디지털교과서 효과성 측정. 동국대학교 교육대학원 석사학위논문.

이영민(2005). 타블렛 컴퓨터를 활용한 모바일 학습사례 분석. 컴퓨터교육학회논문지, 8(1),25-32.

이승훈(2013). 스마트 기기 기반 언어훈련 애플리케이션이 지적장애 학생의 읽기능력에 미치는 효과. 전남대학교 대학원 박사학위논문. 
이영미, 이수복, 성민경(2015). 국내 장애 아동을 위한 언어치료용 모바일 어플리케이션 현황 분석. 말소리와음성과학, 7(3), 153-163.

이재명, 기현영, 이주환(2012). 올드미디어와 뉴미디어를 통한 아동 학습효과의 차이: 동일 컨텐츠의 책, 비디오, 타블렛을 통한 학습 효과 비교. 한국 $\mathrm{HCI}$ 학회 학술대회, 835-837.

이주연, 김영태(2009). 청소년 어휘검사에 있어서 개별 검사와 집단 검사 방법 간의 비교 연구. 언어치료연구, 18(1), 57-72.

유구종(2012). 유아교육기관 스마트폰, 태블릿 PC활용 프로그램 개발 및 유아의 과학적 사고에 미치는 효과. 열린유아교육연구, 17(3), 85-110.

장경은(2018). 사물인터넷 기반의 스마트 폰 애플리케이션을 이용한 격조사 중재가 학령전기 단순언어장애 아동의 격조사 표현 및 발화길이에 미치 는 영향. 이화여자대학교 대학원 석사학위논문.

정민경(2015). PC 및 휴머노이드 로봇을 이용한 감정 이야기 중재가 고기능 자폐아동의 감정 어휘 표현에 미치는 영향. 이화여자대학교 대학원 석사 학위논문.

조미경(2012). 인터넷 애니메이션 동화를 활용한 언어중재가 지적장애 아동의 이야기이해력 및 구문이해력에 미치는 효과. 대구대학교 재활과학대 학원 석사학위논문.

홍경훈, 김영태, 김수진(2014). 3세 아동용 간편어휘력 검사 개발을 위한 기초 연구. Communication Sciences \& Disorders, 19(1), 1-8.

\section{ORCID}

박지숙(제1저자, 대학원생 https://orcid.org/0000-0002-5404-1153); 최성희(교신저자, 교수 https://orcid.org/0000-0003-2365-6187); 이경재(공동저자, 교수 https://orcid.org/0000-0002-6811-1212); 최철희(공동저자, 교수 https://orcid.org/0000-0003-1844-3072) 